\title{
Inverse relationship between serum adenosine deaminase levels and islet beta cell function in patients with type 2 diabetes
}

\author{
Jie Cao ${ }^{1 \dagger}$, Hong Wang ${ }^{1 \dagger}$, Jian-bin Su ${ }^{1 *}$ (]), Xue-qin Wang ${ }^{1 *}$, Dong-mei Zhang ${ }^{2}$, Xiao-hua Wang ${ }^{1}$,
}

Wang-shu Liu' and Xiao-qin Ge ${ }^{1}$

\begin{abstract}
Objective: Type 2 diabetes (T2D) is a chronic low-grade inflammatory disease, which characterized by islet beta cell dysfunction. Serum adenosine deaminase (ADA) is an important enzyme that regulates the biological activity of insulin, and its levels are greatly increased in inflammatory diseases with insulin resistance. The present study was designed to explore the relationship between serum ADA levels and islet beta cell function in patients with T2D.

Methods: This cross-sectional study recruited 1573 patients with T2D from the Endocrinology Department of the Affiliated Hospital 2 of Nantong University between 2015 and 2018. All participants were received serum ADA test and oral glucose tolerance test (OGTT). Insulin sensitivity index (assessed by Matsuda index using C-peptide, ISI $\left.\right|_{M-c p}$ ), insulin secretion index (assessed by ratio of area under the C-peptide curve to glucose curve, $A \cup C_{\mathrm{cp} / \mathrm{glu}}$ ) and islet beta cell function (assessed by insulin secretion-sensitivity index 2 using C-peptide, ISSI $2_{\mathrm{cp}}$ ) were derived from OGTT. And other clinical parameters, such as HbA1c, were also collected.

Results: It was showed that $\mathrm{HbA} 1 \mathrm{c}$ was significantly increased, while $\left.I S\right|_{\mathrm{M}-\mathrm{cp}}, A U C_{\mathrm{cp} / \mathrm{qlu}}$ and $I S S \mid 2_{\mathrm{cp}}$ significantly decreased, across ascending quartiles of serum ADA levels. Moreover, serum ADA levels were negatively correlated with $I S S I 2_{c p}(r=-0.267, p<0.001)$. Furthermore, after adjusting for other clinical parameters by multiple linear regression analysis, serum ADA levels were still independently associated with $I S S I 2_{c p}(\beta=-0.125, t=-5.397, p<0.001$, adjusted $R^{2}=0.459$ ).
\end{abstract}

Conclusions: Serum ADA levels are independently associated with islet beta cell function in patients with T2D.

Keywords: Adenosine deaminase, Islet beta cell function, Type 2 diabetes

\section{Introduction}

Adenosine deaminase (ADA) is a key enzyme in purine metabolism that catalyzes the irreversible conversion of adenosine and deoxyadenosine to inosine and deoxyinosine, respectively $[1,2]$. ADA is extensively expressed in

\footnotetext{
*Correspondence: sujbzjx@163.com; wangxueqin108@163.com ${ }^{\dagger} \mathrm{Jie}$ Cao and Hong Wang contributed equally to this work ${ }^{1}$ Department of Endocrinology, Affiliated Hospital 2 of Nantong University, and First People's Hospital of Nantong City, No. 6, Haierxiang North Road, Nantong 226001, China

Full list of author information is available at the end of the article
}

various human tissues, with the highest activity in thymus, spleen and other lymphoid tissues, and is related to cell mediated immunity [3, 4]. ADA is an important enzyme that regulates the biological activity of insulin [5, 6]. In addition, increasing evidence highlights that adenosine affects insulin secretion and insulin sensitivity, and also plays an important role in regulating islet cell function $[7,8]$. Serum ADA activity is strongly increased in autoimmune diseases, cancers and inflammatory diseases $[4,9]$. Studies have shown that expression and activity of

c) The Author(s) 2021. This article is licensed under a Creative Commons Attribution 4.0 International License, which permits use, sharing, adaptation, distribution and reproduction in any medium or format, as long as you give appropriate credit to the original author(s) and the source, provide a link to the Creative Commons licence, and indicate if changes were made. The images or other third party material in this article are included in the article's Creative Commons licence, unless indicated otherwise in a credit line to the material. If material is not included in the article's Creative Commons licence and your intended use is not permitted by statutory regulation or exceeds the permitted use, you will need to obtain permission directly from the copyright holder. To view a copy of this licence, visit http://creativeco mmons.org/licenses/by/4.0/. The Creative Commons Public Domain Dedication waiver (http://creativecommons.org/publicdomain/ zero/1.0/) applies to the data made available in this article, unless otherwise stated in a credit line to the data. 
ADA are directly related to the degree of inflammation $[1,5]$.

Type 2 diabetes (T2D) is a complex disease caused by polygenic inheritance and environmental interactions, which characterized by chronic low-grade inflammation and hyperglycemia [10-13]. It is well known that insulin resistance and islet beta cell dysfunction are the pathophysiological mechanisms of T2D [14, 15]. Recent studies showed that serum ADA levels and its isoenzymes are significantly higher in patients with T2D than in healthy controls $[1,5]$. In addition, serum ADA levels were positively correlated with fasting plasma glucose (FPG), postprandial plasma glucose (PPG) and glycated hemoglobin (HbA1c) in patients with T2D $[1,5,16]$. However, a previous study by Khemka et al. [17] showed that there was no correlation between serum ADA levels and HbA1c in patients with T2D. Moreover, the relationship between serum ADA levels and islet beta cell function in T2D has not been fully elucidated.

Hyperglycemic and euglycemic clamp techniques are internationally recognized as "gold standard" for evaluating insulin secretion and insulin sensitivity, respectively [18]. However, these techniques are so expensive and timeconsuming that cannot be widely carried out in clinical practice and large-scale epidemiological studies. Surrogate measures of insulin sensitivity and insulin secretion can be calculated from the results of oral glucose tolerance test (OGTT). Matsuda index $\left(\mathrm{ISI}_{\mathrm{M}-\mathrm{cp}}\right)$ was used to evaluate the sensitivity of liver and peripheral tissues to insulin, and the ratio of total area under the $\mathrm{C}$-peptide curve to area under the glucose curve $\left(\mathrm{AUC}_{\mathrm{cp} / \mathrm{glu}}\right)$ was used to evaluate the insulin secretion $[19,20]$. Furthermore, the insulin secretionsensitivity index 2 using C-peptide (ISSI2 ${ }_{\mathrm{cp}}$ ), which was the product of $\mathrm{ISI}_{\mathrm{M}-\mathrm{cp}}$ and $\mathrm{AUC}_{\mathrm{cp} / \mathrm{glu}}$, was an integrated indicator of islet beta cell function based on OGTT [21, 22].

Therefore, the present cross-sectional study was designed to investigate the relationship between serum ADA levels and islet beta cell function in patients with T2D.

\section{Methods}

\section{Study population}

This cross-sectional study recruited 1573 individuals, including 890 men and 683 women, who were admitted to the Endocrinology Department of the Affiliated Hospital 2 of Nantong University between 2015 and 2018. The inclusion criteria were (1) diagnosis of T2D according to the statement by the American Diabetes Association in 2011 [23] and (2) serum ADA levels in the normal range of $5-25 \mathrm{U} / \mathrm{L}$. The exclusion criteria were as follows: (1) type 1 diabetes; (2) acute complications of diabetes; (3) fasting C-peptide $<0.5 \mathrm{ng} / \mathrm{ml}$; (4) excessive drinking, with alcohol intake $>30 \mathrm{~g}$ daily for men and $>20$ g daily for women; (5) pregnancy; (6) chronic kidney disease stages 4 and 5; (7) chronic liver disease; (8) abnormal thyroid function; (9) malignant tumors; (10) connective tissue disease; (11) tuberculosis. The study was approved by the ethics committee of the Second Affiliated Hospital of Nantong University and conformed to the Helsinki Declaration.

\section{Basic data collection}

Since all recruited patients were inpatients, the clinical information, physical examination, biochemical data and imaging data could be obtained from the hospital information platform. The main medical history included age, sex, height, weight, systolic blood pressure (SBP), diastolic blood pressure (DBP), diabetes duration, past illness (i.e., hypertension, malignant tumors, thyroid dysfunction, rheumatic diseases, etc.), current medications taken (i.e., statins and antihypertensives) and glucose-lowering therapies (i.e., lifestyle alone, insulin secretagogues, metformin, pioglitazone, glucosidase inhibitors, DPP4Is, insulin treatments, etc.). Body mass index (BMI) was calculated as weight/the height squared.

\section{Laboratory data collection}

After an overnight fasting, venous blood samples were collected from all recruited patients for biochemical indices. The FPG, triglyceride (TG), total cholesterol (TC), high-density lipoprotein cholesterol (HDLC), low-density lipoprotein cholesterol (LDLC), alanine aminotransferase (ALT) and aspartate aminotransferase (AST) were measured with an automated biochemical analyzer (Model 7600, Hitachi). Serum C-peptide levels were measured with the electrochemiluminescence immunoassays in an immunoassay system (DxI 800, Beckman Coulter). The intra and inter-assay variation coefficients of C-peptide were $2.0-2.8 \%$ and $2.3-3.5 \%$, respectively. HbA1c was measured with the ion exchange-based HPLC method in a hemoglobin analysis system (D-10 Testing Program, Bio-Rad). Serum ADA levels were measured by the adenosine deaminase reagent kit (MedicalSystem Biotechnology Company Limited, Ningbo, China) using an automated biochemical analyzer (Model 7600, Hitachi).

\section{OGTT procedures and islet beta cell function}

A standard 75-g oral glucose tolerance test (OGTT) was performed after at least $8 \mathrm{~h}$ fast in the morning, and venous blood samples were collected at fasting (0) and at 30,60, 120 and $180 \mathrm{~min}$ after the glucose load to detect serum glucose and C-peptide levels. We applied C-peptide to evaluate endogenous insulin levels. Fasting insulin sensitivity index was determined with the 
following equation: $\mathrm{IS}_{\mathrm{HOMA}-\mathrm{cp}}=22.5 /$ (fasting glucose $\times$ fasting C-peptide) $[19,20]$. Systemic insulin sensitivity index was calculated by the following equation: $\mathrm{ISI}_{\mathrm{M}-\mathrm{cp}}=10,000 /$ square root of (fasting glucose $\times$ fasting C-peptide $) \times($ mean glucose $\times$ mean $C$-peptide during OGTT) $[19,20]$. The area under the $C$-peptide curve $\left(\mathrm{AUC}_{\mathrm{cp}}\right)$ and the area under the glucose curve $\left(\mathrm{AUC}_{\mathrm{glu}}\right)$ were computed using the trapezoidal rule. The ratio of total area under the $\mathrm{C}$-peptide curve to area under the glucose curve $\left(\mathrm{AUC}_{\mathrm{cp} / \mathrm{glu}}\right)$ was used to evaluate the insulin secretion index. ISSI $2_{\mathrm{cp}}$ was calculated by multiplying $\mathrm{AUC}_{\mathrm{cp} / \mathrm{glu}}$ and $\mathrm{ISI}_{\mathrm{M}-\mathrm{cp}}[21,22]$.

\section{Statistical analyses}

Statistical analyses of the data were performed using SPSS (version 25.0) software. All participants were categorized by quartiles of serum ADA levels. All continuous variables with normal distribution were expressed as the mean \pm standard deviation (SD) or skewed distributions were expressed as median (interquartile range). Whereas categorical variables were expressed as frequencies (percentages). If the variables were non-normally distributed, logarithmic transformations were applied to achieve a normal distribution. The one-way analysis of variance (ANOVA) was performed to compare differences in the continuous variables between serum ADA levels quartiles, and the Chi squared test was performed to compare categorical variables among the four subgroups. Pearson's correlation test and partial correlation test were conducted to analyze the correlation between serum ADA levels and ISSI $2_{\mathrm{cp}}$. Moreover, multiple linear regression analysis was performed to explore the relationship between serum ADA levels and ISSI2 $2_{\mathrm{cp}}$ as the dependent variable. A $p$ value $<0.05$ was considered to indicate a statistically significant.

\section{Results}

\section{Clinical characteristics of study participants}

A total of 1573 participants diagnosed with T2D were recruited in this study and divided into four subgroups according to serum ADA levels. The clinical characteristics of the participants according to the quartiles of serum ADA levels are shown in the Table 1 . The recruited participants had normal serum ADA levels of 13.6 (11.116.9) $\mathrm{U} / \mathrm{L}$, diabetes duration of $78.64 \pm 74.45$ months, ages of $58.17 \pm 13.12$ years, BMI of $25.75 \pm 3.58 \mathrm{~kg} / \mathrm{m}^{2}$ and HbA1c levels of $9.02 \pm 4.43 \%$. The serum ADA levels of the total participants were $13.6(11.1-16.9) \mathrm{U} / \mathrm{L}$, and of the quartiles were Q1 $(9.5(8.5-10.3) \mathrm{U} / \mathrm{L}), \mathrm{Q} 2$ (12.4 (12.4-13.1)U/L), Q3 (15.0 (14.3-16.0)U/L) and Q4 (19.7 (18.1-21.7)U/L), respectively. As serum ADA levels quartiles increased, age, ratio of female to male, diabetes duration, ratio of hypertension, SBP, ALT and AST significantly increased (all $p$ values for trend $<0.05$ ), while BMI, DBP, TG, TC, HDLC and LDLC showed no differences (all $p$ values for trend $>0.05$ ). As the serum ADA levels quartiles increased, serum HbA1c increased from $8.19 \pm 2.02 \%$ to $8.91 \pm 1.92 \%$ to $9.06 \pm 1.98 \%$ to $9.89 \pm 2.15 \% \quad(p<0.001)$. Additionally, comparisons of glucose-lowering therapies showed that the frequency of insulin treatments and glucosidase inhibitors use were increased, whereas intervention by lifestyle alone was decreased, as serum ADA levels quartiles increased (all $p$ values for trend $<0.05$ ).

The islet beta cell function indexes derived from OGTT for the all participants and the four subgroups are summaried in Table 2. The serum glucose levels at $0,30,60$, 120 , and $180 \mathrm{~min}$ were significantly increased from Q1 to Q4 of serum ADA levels (all $p$ values for trend $<0.05$ ). The serum C-peptide levels at 30, 60 and 120 min were significantly decreased from Q1 to Q4 of serum ADA levels (all $p$ values for trend $<0.05$ ), whereas there were no differences of serum C-peptide levels at 0 and $180 \mathrm{~min}$ among the four subgroups (all $p$ values for trend $>0.05$ ). Furthermore, the major metabolic parameters $\mathrm{IS}_{\text {HOMA-cp}}$, ISI $_{\mathrm{M}-\mathrm{cp}}, \mathrm{AUC}_{\mathrm{cp} / \mathrm{glu}}$ and ISSI2 $2_{\mathrm{cp}}$ were decreased from QI to Q4 of serum ADA levels (all $p$ values for trend $<0.01$ ).

\section{Relationship between serum ADA levels and islet beta cell function}

The results of Person correlation between serum ADA levels and ISSI2 $2_{\text {cp }}$ was presented in Fig. 1. The serum ADA levels were significantly and negatively correlated with $\operatorname{ISSI} 2_{\mathrm{cp}}(r=-0.267, p<0.001)$. Moreover, after adjusting for HbA1c, the association between serum ADA levels and $\mathrm{ISSI} 2_{\mathrm{cp}}$ was still existed $(r=-0.156$, $p<0.001)$.

\section{Multiple liner regression analysis with islet beta cell function index as the dependent variable}

The association of serum ADA levels and islet beta cell function index (ISSI2 $2_{\mathrm{cp}}$ ) was showed in Table 3 by multiple linear regression analyses, with ISSI $2_{\mathrm{cp}}$ as the dependent variable. In the basal unadjusted model 1 , serum ADA levels were significantly associated with ISSI $2_{\mathrm{cp}}$ $\left(\beta=-0.267, t=-10.994, p<0.001\right.$, adjusted $\left.R^{2}=0.071\right)$. In model 2, we adjusted for age, sex, BMI, SBP, DBP, diabetes duration, ALT, AST, TG, TC, HDLC, LDLC, Cr, $\mathrm{IS}_{\text {HOMA-cp }}$ and HbA1c and observed a gradual increase in the adjusted $R^{2}$. In the fully adjusted model 3 (further adjusted for statin medication and glucose-lowering therapies), serum ADA levels were still independently associated with ISSI2 ${ }_{\text {cp }}(\beta=-0.125, t=-5.397, p<0.001$, adjusted $R^{2}=0.459$ ). 
Table 1 Clinical characteristics of the study participants according to the quartiles of serum ADA levels

\begin{tabular}{|c|c|c|c|c|c|c|}
\hline Variables & Total & Q1 & Q2 & Q3 & Q4 & $p$ value \\
\hline $\mathrm{ADA}(\mathrm{U} / \mathrm{L})$ & $13.6(11.1-16.9)$ & $9.5(8.5-10.3)$ & $12.4(12.4-13.1)$ & $15.0(14.3-16.0)$ & $19.7(18.1-21.7)$ & $<0.001$ \\
\hline$n$ & 1573 & 396 & 399 & 388 & 390 & - \\
\hline Age (year) & $58.17 \pm 13.12$ & $53.79 \pm 11.98$ & $56.74 \pm 12.78$ & $59.12 \pm 12.94$ & $63.13 \pm 13.01$ & $<0.001$ \\
\hline Female (F/M) & $683 / 890$ & $125 / 271$ & $176 / 223$ & $182 / 206$ & 200/190 & $<0.001$ \\
\hline Diabetes duration (months) & $78.64 \pm 74.45$ & 63.5 & $76.56 \pm 71.82$ & $81.01 \pm 74.15$ & $93.80 \pm 85.09$ & $<0.001$ \\
\hline \multicolumn{7}{|l|}{ Glucose-lowering therapies } \\
\hline Lifestyle alone, n (\%) & 105 & $35(33.3)$ & $22(21.0)$ & $35(24.7)$ & $13(12.4)$ & 0.003 \\
\hline Insulin treatments, n (\%) & 805 & $158(19.6)$ & $203(25.2)$ & $203(25.2)$ & $241(29.9)$ & $<0.001$ \\
\hline Insulin-secretagogues, n (\%) & 822 & $199(24.2)$ & $219(26.6)$ & $191(23.2)$ & $213(25.9)$ & 0.257 \\
\hline Metformin, n (\%) & 904 & $236(26.1)$ & $233(25.8)$ & $215(23.8)$ & $220(24.3)$ & 0.632 \\
\hline Pioglitazone, n (\%) & 571 & $137(24.0)$ & $148(25.9)$ & $133(23.3)$ & $153(26.8)$ & 0.433 \\
\hline Glucosidase inhibitors, n (\%) & 388 & $66(17.0)$ & $91(23.5)$ & $103(26.5)$ & $128(33.0)$ & $<0.001$ \\
\hline DPP-4Is, n (\%) & 433 & $93(21.5)$ & $118(27.3)$ & $103(23.8)$ & $119(27.5)$ & 0.111 \\
\hline Statin medication, n (\%) & 567 & $128(22.6)$ & $161(28.4)$ & $140(24.7)$ & $138(24.3)$ & 0.129 \\
\hline Hypertension, n (\%) & $804(51.1)$ & $177(44.7)$ & $205(51.4)$ & $198(51.0)$ & $224(57.4)$ & 0.005 \\
\hline $\mathrm{BMI}\left(\mathrm{kg} / \mathrm{m}^{2}\right)$ & $25.75 \pm 3.58$ & $25.51 \pm 3.47$ & $25.82 \pm 3.49$ & $25.85 \pm 3.76$ & $25.82 \pm 3.62$ & 0.518 \\
\hline $\mathrm{SBP}(\mathrm{mmHg})$ & $137.20 \pm 18.02$ & $134.86 \pm 17.80$ & $137.36 \pm 17.75$ & $137.78 \pm 17.49$ & $138.85 \pm 18.86$ & 0.016 \\
\hline $\mathrm{DBP}(\mathrm{mmHg})$ & $79.81 \pm 10.89$ & $80.24 \pm 10.51$ & $80.09 \pm 10.48$ & $79.93 \pm 11.24$ & $78.96 \pm 11.31$ & 0.349 \\
\hline $\mathrm{ALT}(\mathrm{U} / \mathrm{L})$ & $18(13-28)$ & $17(12-26)$ & $19(13-28)$ & $19(14-30)$ & $19(13-29)$ & 0.023 \\
\hline AST $(U / L)$ & $17(14-22)$ & $15(13-20)$ & $16(14-21)$ & $17(14-23)$ & $18(15-25)$ & $<0.001$ \\
\hline $\mathrm{TG}(\mathrm{mmol} / \mathrm{L})$ & $1.83(1.18-2.92)$ & $1.75(1.11-2.83)$ & $1.99(1.27-3.15)$ & $1.75(1.18-2.86)$ & $1.83(1.21-2.84)$ & 0.138 \\
\hline $\mathrm{TC}(\mathrm{mmol} / \mathrm{L})$ & $4.51 \pm 1.36$ & $4.41 \pm 1.06$ & $4.59 \pm 0.98$ & $4.56 \pm 1.44$ & $4.50 \pm 1.14$ & 0.172 \\
\hline $\mathrm{HDLC}(\mathrm{mmol} / \mathrm{L})$ & $1.04 \pm 0.27$ & $1.05 \pm 0.28$ & $1.04 \pm 0.25$ & $1.04 \pm 0.28$ & $1.03 \pm 0.28$ & 0.757 \\
\hline LDLC (mmol/L) & $2.57 \pm 0.79$ & $2.52 \pm 0.82$ & $2.64 \pm 0.78$ & $2.57 \pm 0.76$ & $2.54 \pm 0.82$ & 0.225 \\
\hline HbA1c (\%) & $9.02 \pm 4.43$ & $8.19 \pm 2.02$ & $8.91 \pm 1.92$ & $9.06 \pm 1.98$ & $9.89 \pm 2.15$ & $<0.001$ \\
\hline
\end{tabular}

\section{Discussion}

In the current study, we analyzed the relationship between serum ADA levels in the normal range and insulin sensitivity, insulin secretion and islet beta cell function in patients with T2D. The main finding of the current study showed that serum ADA levels were inversely associated with islet beta cell function assessed by ISSI $2_{\mathrm{cp}}$.

The pathogenic mechanisms of T2D are insulin resistance and islet beta cell dysfunction, which characterized by chronic low-grade inflammation. Previous studies have proven that the defects in insulin action of T-lymphocyte may play an important role in inappropriate immune responses in T2D [24]. ADA is more active in T-lymphocyte than in B-lymphocyte, and it plays an important role in lymphocyte proliferation, differentiation, and maturation [25, 26]. A small-scale study by Khemka et al. [17] demonstrate that serum ADA levels were significantly higher in nonobese T2D subjects than in healthy controls, and were positively correlation with FPG in these T2D subjects. A recent cross-sectional study found that serum ADA levels were significantly increased in uncontrolled diabetes (HbA1c $>7 \%)$ when compared to healthy controls and controlled diabetes
(HbA1c $<7 \%)$, and were significantly positive correlated with FPG and HbA1c [5]. And our study showed that as serum ADA levels quartiles increased, FPG and HbA1c were increased. Our study is consistent with these previous findings. Thus, it is suggested that the increased serum ADA levels may indicate the immune dysfunction and poor glycemic control in T2D.

Previous studies have shown that ADA is an important enzyme that modulates the insulin bioactivity $[6,27,28]$. In addition, $\mathrm{ADA}$ is an important enzyme in regulating adenosine concentration by inactivation of adenosine, and adenosine plays a critical role in modulating glucose and insulin homeostasis and the pathophysiology of T2D [7, 8, 29]. Dhalla et al. [30] revealed that adenosine $A_{1}$ receptor agonist decreased the levels of free fatty acids (FFA) and triglycerides and improved the insulin resistance induced by high-fat diet in mice. Johansson et al. [31] demonstrated that adenosine increased insulin sensitivity for glucose transport in $\mathrm{A}_{1} \mathrm{R}$ knock out mice. Ohtani et al. [32] showed that the activation of adenosine $\mathrm{A}_{2 \mathrm{a}}$ receptor by adenosine resulted in increased insulin secretion in mouse pancreatic islets. C-peptide levels reflect endogenous insulin secretion more accurately 


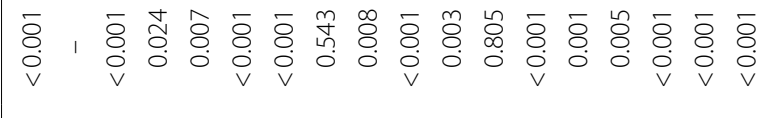

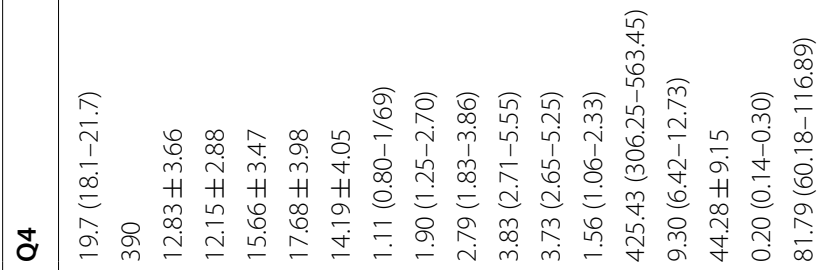

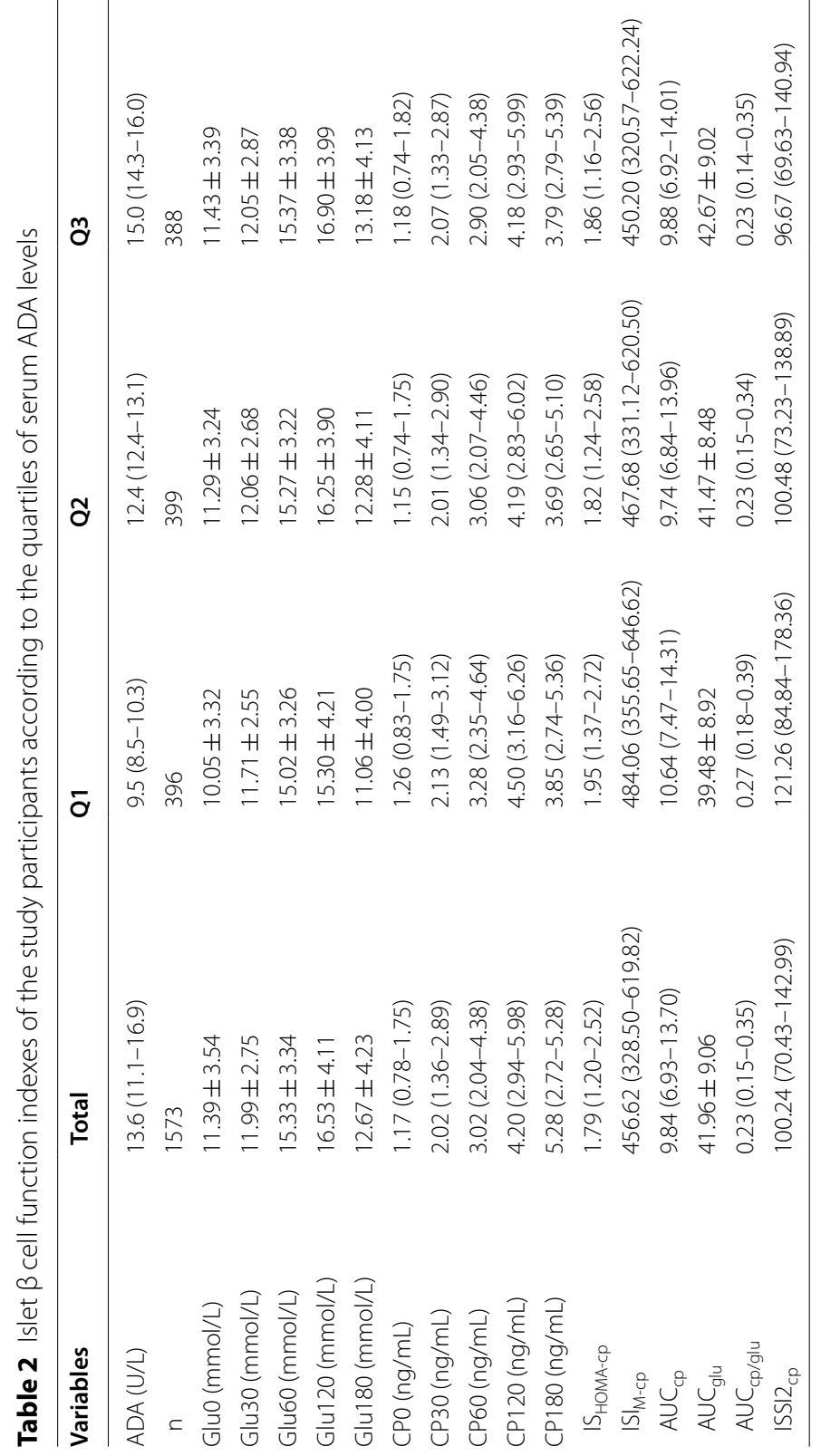



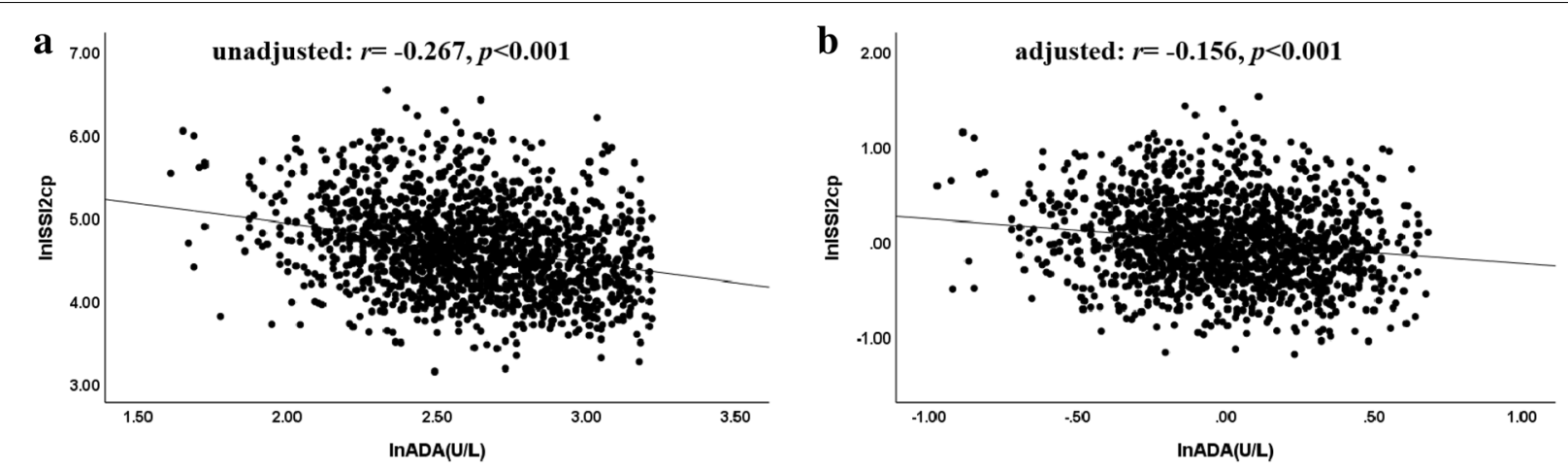

Fig. 1 The relationship between the serum ADA levels and ISSI2 ${ }_{c p}$ (a unadjusted; $\mathbf{b}$ adjusted for HbA1c)

Table 3 Multiple liner regression analysis on $1 \mathrm{SSI} 2_{\mathrm{cp}}$

\begin{tabular}{lllll}
\hline Model & $\boldsymbol{\beta}$ & $\boldsymbol{t}$ & $\boldsymbol{p}$ value & Adjusted $\boldsymbol{R}^{\mathbf{2}}$ \\
\hline Model 1 & -0.267 & -10.994 & $<0.001$ & 0.071 \\
Model 2 & -0.131 & -5.539 & $<0.001$ & 0.426 \\
Model 3 & -0.125 & -5.397 & $<0.001$ & 0.459 \\
\hline
\end{tabular}

Model 1: Unadjusted

Model 2: Adjusted for age, sex, BMI, SBP, DBP, diabetes duration, ALT, AST, TG, TC, HDLC, LDLC, IS HOMA-cp $_{\text {and } \mathrm{HbA1C}}$

Model 3: Additionally adjusted for statin medication and glucose-lowering therapies

than insulin levels. Our study showed that serum ADA levels were negatively correlated with fasting insulin sensitivity index measured by IS $_{\text {HOMA-cp }}$, systemic insulin sensitivity index measured by $\mathrm{ISI}_{\mathrm{M}-\mathrm{cp}}$ and insulin secretion index measured by $\mathrm{AUC}_{\mathrm{cp} / \mathrm{glu}}$. Our data in a large population were consistent with previous studies. Therefore, serum ADA levels were negatively correlated with insulin sensitivity and insulin secretion in patients with T2D.

Serum ADA levels may also be a potential biomarker closely related to overall islet beta cell function. We applied ISSI $2_{\mathrm{cp}}$ to evaluate integrated islet beta cell function. Retnakaran et al. $[20,22]$ proposed that ISSI $2_{\mathrm{cp}}$ was a potential OGTT-based method for measuring islet cell function. And ISSI2 $2_{\mathrm{cp}}$ has been proven to measure the ability of islet beta cell to compensate for changes in systemic insulin sensitivity through changes in insulin secretion [33]. There are few studies about ADA and islet beta cell function, while a large number of studies have suggested that adenosine plays a role in regulating proliferation and survival of beta cell [32, 34]. Andersson et al. [35] demonstrated that adenosine agonist increased the proliferation of beta cell and accelerated the recovery of normoglycemia through the adenosine $\mathrm{A}_{2 \mathrm{aa}}$ receptor in a zebrafish model of diabetes. Our study proved that serum ADA levels were negatively correlated with $\operatorname{ISSI} 2_{\mathrm{cp}}$.
Moreover, our study suggested that serum ADA levels were independently associated with ISSI $2_{\mathrm{cp}}$ after multiple liner stepwise regression analysis in patients with T2D. Further research is needed to explore the relationship between ADA and islet beta cell function, and to explore the causal relationship among them.

There are few studies on the relationship between ADA and insulin sensitivity, insulin secretion and islet beta cell function. And their mechanism remains unclear, but their relationship may be explained as follows. Adenosine stimulates insulin activity in the processes of lipid synthesis, glucose transport, leucine oxidation and pyruvate dehydrogenase activity. Adenosine plays a critical role in regulating the activity of insulin in liver tissue, adipose tissue, cardiac muscle and skeletal muscle $[8,16,36,37]$. Moreover, adenosine regulates the homeostasis of beta cell by controlling the proliferation and regeneration of beta cell $[34,38,39]$. ADA is a critical enzyme to regulate adenosine concentration. Thus, higher ADA activity in patients with T2D reduces adenosine levels which affects glucose homeostasis. Moreover, DDPIV/CD26 is a transmembrane glycoprotein. On the surface of $\mathrm{T}$ lymphocytes, ADA binds to DDPIV via adenosine $\mathrm{A}_{2 \mathrm{~b}}$ receptor, which inhibits the glucagon-like peptide-1 (GLP-1) $[16,40]$. And GLP-1 plays an important role in promoting insulin secretion, inhibiting glucagon secretion and stimulating the proliferation and differentiation of islet beta cell in patients with diabetes. In patients with T2D, the relationship between ADA and islet beta cell and its mechanism are still unclear, which needs the further study.

Several limitations of our study should be addressed. First, the current study was a cross-sectional observational study that cannot determine the causal association between serum ADA levels and islet beta cell function. Besides, Prospective longitudinal studies are needed to assess the casual relationship. Second, hyperglycemic and euglycemic clamp techniques are the gold standard 
for evaluating insulin secretion and insulin sensitivity, respectively. However, insulin sensitivity and islet beta cell function derived from the OGTT was more practical for the large-scale clinical study. Third, the current study may be restricted to Chinese population and lack generalizability to other population. Fourth, ADA has two isoenzymes ADA1 and ADA2, which may paly different roles in T2D and other metabolic disease. This may require further research to distinguish between the two isoenzymes for clinical relevance analysis. Fifth, after adjusting for other clinical confounders via multiple linear regression analyses, serum ADA levels were still independently associated with ISSI $2_{\mathrm{cp}}$. The $\beta$ value is relative small $(\beta=-0.125)$, although it is significant. Therefore, we need more experiments to further investigate the relationship between serum ADA levels and islet beta cell function and their mechanism.

\section{Conclusions}

In conclusion, serum ADA levels within the normal range are negatively associated with islet beta cell function assessed by ISSI $2_{\mathrm{cp}}$ in patients with T2D.

\begin{abstract}
Abbreviations
ADA: Adenosine deaminase; T2D: Type 2 diabetes; FPG: Fasting plasma glucose; PPG: Postprandial plasma glucose; HbA1c: Glycated hemoglobin; OGTT: Oral glucose tolerance test; $\mid \mathrm{SI} \mathrm{M}_{\mathrm{M}-\mathrm{cp}}$ : Matsuda index; $\mathrm{AUC}_{\mathrm{cp} / \mathrm{glu}}$ : The ratio of total area under the C-peptide curve to area under the glucose curve; ISSI2 ${ }_{\mathrm{CP}}$ : Insulin secretion-sensitivity index 2; SBP: Systolic blood pressure; DBP: Diastolic blood pressure; BMI: Body mass index; TG: Triglyceride; TC: Total cholesterol; HDLC: High-density lipoprotein cholesterol; LDLC: Low-density lipoprotein cholesterol; ALT: Alanine aminotransferase; AST: Aspartate aminotransferase; Cr: Creatinine; FFA: Free fatty acids; GLP-1: Glucagon-like peptide-1.
\end{abstract}

\section{Acknowledgements}

Not applicable.

\section{Authors' contributions}

JC, XqW and HW participated in the design of the study, data collection, analysis of the data, and drafting of the manuscript. JbS and JC conceived of the study, participated in its design and revised the manuscript. JC and HW participated in the analysis of the data and revised the manuscript. JC, XqW, XhW, DmZ, WsL and XqG participated in data collection. All authors read and approved the final manuscript.

\section{Funding}

The study was funded by the Social Development Projects of Nantong (JC2019037, MS12019019, HS2020005), the Medical Research Project of Nantong Health Commission (2020JCC010), and the Medical Research Project of Nantong University (2019HY002).

\section{Availability of data and materials}

The current data are available to all interested researchers upon reasonable request. Requests for access to data should be made to the principal investigators of the study.

\section{Declarations}

\section{Ethics approval and consent to participate}

The study was approved by the institutional review board of Affiliated Hospital 2 of Nantong University and First People's Hospital of Nantong City, and written informed consent was obtained from all participants.

\section{Consent for publication}

Not applicable.

\section{Competing interests}

The authors declare that they have no competing interests.

\section{Author details}

${ }^{1}$ Department of Endocrinology, Affiliated Hospital 2 of Nantong University, and First People's Hospital of Nantong City, No. 6, Haierxiang North Road, Nantong 226001, China. ${ }^{2}$ Medical Research Center, Affiliated Hospital 2 of Nantong University, and First People's Hospital of Nantong City, No. 6, Haierxiang North Road, Nantong 226001, China.

Received: 26 January 2021 Accepted: 28 April 2021

Published online: 17 May 2021

\section{References}

1. Sapkota LB, Thapa S, Subedi N. Correlation study of adenosine deaminase and its isoenzymes in type 2 diabetes mellitus. BMJ Open Diabetes Res Care. 2017;5:e000357

2. Bagheri S, Saboury AA, Haertle T. Adenosine deaminase inhibition. Int J Biol Macromol. 2019;141:1246-57.

3. Zavialov AV, Gracia E, Glaichenhaus N, Franco R, Zavialov AV, Lauvau G. Human adenosine deaminase 2 induces differentiation of monocytes into macrophages and stimulates proliferation of T helper cells and macrophages. J Leukoc Biol. 2010;88:279-90.

4. Xuan C, Tian QW, Zhang SY, Li H, Tian TT, Zhao P, et al. Serum adenosine deaminase activity and coronary artery disease: a retrospective case-control study based on 9929 participants. Ther Adv Chronic Dis. 2019;10:2040622319891539.

5. Niraula A, Thapa S, Kunwar S, Lamsal M, Baral N, Maskey R. Adenosine deaminase activity in type 2 diabetes mellitus: does it have any role? BMC Endocr Disord. 2018;18:58.

6. Hoshino T, Yamada K, Masuoka K, Tsuboi I, Itoh K, Nonaka K, et al. Elevated adenosine deaminase activity in the serum of patients with diabetes mellitus. Diabetes Res Clin Pract. 1994;25:97-102.

7. Singh A, Gibert Y, Dwyer KM. The adenosine, adrenergic and opioid pathways in the regulation of insulin secretion, beta cell proliferation and regeneration. Pancreatology. 2018;18:615-23.

8. Antonioli L, Blandizzi C, Csoka B, Pacher P, Hasko G. Adenosine signalling in diabetes mellitus-pathophysiology and therapeutic considerations. Nat Rev Endocrinol. 2015;11:228-41.

9. Lee PY, Schulert GS, Canna SW, Huang Y, Sundel J, Li Y, et al. Adenosine deaminase 2 as a biomarker of macrophage activation syndrome in systemic juvenile idiopathic arthritis. Ann Rheum Dis. 2020;79:225-31.

10. Cuschieri S. The genetic side of type 2 diabetes-a review. Diabetes Metab Syndr. 2019;13:2503-6.

11. Prattichizzo F, De Nigris V, Spiga R, Mancuso E, La Sala L, Antonicelli R, et al. Inflammageing and metaflammation: The yin and yang of type 2 diabetes. Ageing Res Rev. 2018;41:1-17.

12. Bonnet F, Scheen AJ. Effects of SGLT2 inhibitors on systemic and tissue low-grade inflammation: the potential contribution to diabetes complications and cardiovascular disease. Diabetes Metab. 2018;44:457-64.

13 Gomes BF, Accardo CM. Immunoinflammatory mediators in the pathogenesis of diabetes mellitus. Einstein. 2019;17:eRB4596.

14 Chung IM, Rajakumar G, Subramanian U, Venkidasamy B, Khanna VG, Thiruvengadam $M$. Insights on the current status and advancement of diabetes mellitus type 2 and to avert complications: An overview. Biotechnol Appl Biochem. 2019;67:920-8.

15. Eguchi K, Nagai R. Islet inflammation in type 2 diabetes and physiology. J Clin Invest. 2017:127:14-23. 
16. Larijani B, Heshmat R, Ebrahimi-Rad M, Khatami S, Valadbeigi S, Saghiri R. Diagnostic value of adenosine deaminase and its isoforms in type ii diabetes mellitus. Enzyme Res. 2016;2016:9526593.

17. Khemka VK, Bagchi D, Ghosh A, Sen O, Bir A, Chakrabarti S, et al. Raised serum adenosine deaminase level in nonobese type 2 diabetes mellitus. Sci World J. 2013;2013:404320.

18. DeFronzo RA, Tobin JD, Andres R. Glucose clamp technique: a method for quantifying insulin secretion and resistance. Am J Physiol. 1979:237:E214-23.

19. Matsuda M, DeFronzo RA. Insulin sensitivity indices obtained from oral glucose tolerance testing: comparison with the euglycemic insulin clamp. Diabetes Care. 1999;22:1462-70.

20. Radaelli T, Farrell KA, Huston-Presley L, Amini SB, Kirwan JP, McIntyre HD, et al. Estimates of insulin sensitivity using glucose and C-Peptide from the hyperglycemia and adverse pregnancy outcome glucose tolerance test. Diabetes Care. 2010;33:490-4.

21. Wang $X H$, Xu F, Cheng M, Wang $X$, Zhang DM, Zhao LH, et al. Fasting serum total bile acid levels are associated with insulin sensitivity, islet $\beta$-cell function and glucagon levels in response to glucose challenge in patients with type 2 diabetes. Endocr J. 2020;67:1107-17.

22. Retnakaran R, Qi Y, Goran MI, Hamilton JK. Evaluation of proposed oral disposition index measures in relation to the actual disposition index. Diabet Med. 2009;26:1198-203.

23. American DA. Diagnosis and classification of diabetes mellitus. Diabetes Care. 2011;34(Suppl 1):S62-9.

24. Stentz FB, Kitabchi AE. Activated T lymphocytes in Type 2 diabetes: implications from in vitro studies. Curr Drug Targets. 2003;4:493-503.

25 Yordanova M, Gerova D, Atanassova A, Galunska B. Adenosine deaminase as a useful biomarker for diagnosis and monitoring of inflammatory bowel disease. Clin Lab. 2020. https://doi.org/10.7754/clin.lab.2019. 191124.

26. Ebrahimi-Rad M, Khatami S, Ansari S, Jalylfar S, Valadbeigi S, Saghiri R. Adenosine deaminase 1 as a biomarker for diagnosis and monitoring of patients with acute lymphoblastic leukemia. J Med Biochem. 2018;37:128-33.

27. Franco R, Valenzuela A, Lluis C, Blanco J. Enzymatic and extraenzymatic role of ecto-adenosine deaminase in lymphocytes. Immunol Rev. 1998;161:27-42.

28. Kurtul N, Pence S, Akarsu E, Kocoglu H, Aksoy Y, Aksoy H. Adenosine deaminase activity in the serum of type 2 diabetic patients. Acta Medica. 2004;47:33-5.

29. Peleli M, Carlstrom M. Adenosine signaling in diabetes mellitus and associated cardiovascular and renal complications. Mol Aspects Med. 2017:55:62-74
30. Dhalla AK, Wong MY, Voshol PJ, Belardinelli L, Reaven GM. A1 adenosine receptor partial agonist lowers plasma FFA and improves insulin resistance induced by high-fat diet in rodents. Am J Physiol Endocrinol Metab. 2007;292:E1358-63.

31. Johansson SM, Lindgren E, Yang JN, Herling AW, Fredholm BB. Adenosine A1 receptors regulate lipolysis and lipogenesis in mouse adipose tissueinteractions with insulin. Eur J Pharmacol. 2008;597:92-101.

32. Ohtani M, Oka T, Ohura K. Possible involvement of A (2)A and A (3) receptors in modulation of insulin secretion and beta-cell survival in mouse pancreatic islets. Gen Comp Endocrinol. 2013;187:86-94.

33. Placzkowska S, Pawlik-Sobecka L, Kokot I, Piwowar A. Estimation of reference intervals of insulin resistance (HOMA), insulin sensitivity (Matsuda), and insulin secretion sensitivity indices (ISSI-2) in Polish young people. Ann Agric Environ Med. 2020;27:248-54.

34. Faulhaber-Walter R, Jou W, Mizel D, Li L, Zhang J, Kim SM, et al. Impaired glucose tolerance in the absence of adenosine $\mathrm{A} 1$ receptor signaling. Diabetes. 2011;60:2578-87.

35. Andersson O, Adams BA, Yoo D, Ellis GC, Gut P, Anderson RM, et al. Adenosine signaling promotes regeneration of pancreatic beta cells in vivo. Cell Metab. 2012;15:885-94

36. Figler RA, Wang G, Srinivasan S, Jung DY, Zhang Z, Pankow JS, et al. Links between insulin resistance, adenosine A2B receptors, and inflammatory markers in mice and humans. Diabetes. 2011;60:669-79.

37. Thong FS, Lally JS, Dyck DJ, Greer F, Bonen A, Graham TE. Activation of the A1 adenosine receptor increases insulin-stimulated glucose transport in isolated rat soleus muscle. Appl Physiol Nutr Metab. 2007;32:701-10.

38. Andersson $\mathrm{O}$. Role of adenosine signalling and metabolism in beta-cell regeneration. Exp Cell Res. 2014;321:3-10.

39. Annes JP, Ryu JH, Lam K, Carolan PJ, Utz K, Hollister-Lock J, et al. Adenosine kinase inhibition selectively promotes rodent and porcine islet beta-cell replication. Proc Natl Acad Sci USA. 2012;109:3915-20.

40. Gracia E, Perez-Capote K, Moreno E, Barkesova J, Mallol J, Lluis C, et al. A2A adenosine receptor ligand binding and signalling is allosterically modulated by adenosine deaminase. Biochem J. 2011;435:701-9.

\section{Publisher's Note}

Springer Nature remains neutral with regard to jurisdictional claims in published maps and institutional affiliations.
Ready to submit your research? Choose BMC and benefit from:

- fast, convenient online submission

- thorough peer review by experienced researchers in your field

- rapid publication on acceptance

- support for research data, including large and complex data types

- gold Open Access which fosters wider collaboration and increased citations

- maximum visibility for your research: over $100 \mathrm{M}$ website views per year

At BMC, research is always in progress.

Learn more biomedcentral.com/submissions 